\title{
An Attempt for Construction of Carbonate Platform Geometry from Devonian Hajigak Formation, Central Afghanistan, with the Help of Facies Analysis and Petrography
}

\author{
Mohammad Naeem Sarwary $^{1}$, Mirza Hussain AmirkhaniT ${ }^{2}$, Hassan Malistani ${ }^{3}$ \\ Msc. Geology, Ghazni Technical University, Ghazni, Afghanistan 1,2 \\ Phd Geology, Bamyan University, Bamyan, Afghanistan ${ }^{3}$ \\ Email: sarwarynaeem5@gmail.com
}

\begin{abstract}
:
The subject of sedimentology fundamentally remained subdivided into two sectors viz. siliciclastic and carbonate with the understanding that these two systems are mutually dissociative in terms of their genesis. Even in the highly referred textbooks, siliciclastics and carbonates are always discussed in separate sections. Presumably, the limited occurrences of mixed siliciclasticcarbonate sediments in nature are because of constraining effects that siliciclastics have on carbonate-secreting organisms; the two sediments rarely found mutually associated in nature. Although the mixed carbonate-siliciclastic sediments are subordinate in occurrence, their presence in some instances proved that they do not represent any geological oddity. Rather, their sedimentological history may tell us a great deal about the dynamics and interactions of facies, paleoecologies of many carbonate-secreting organisms, and tectonic histories of depositional basins.
\end{abstract}

Keeping this in mind, the present study made an attempt to recognize and draw the paleoenvironmental conditions and processes of the Devonian Hajigak Formation, Afghanistan by means of detailed facies analysis and petrographical signatures. An attempt has also been made to characterize sandstone wedges that punctuate the carbonate succession and some variable deposits of shales and marls. 
The Hajigak Formation overlies the Greenschist Formation and is made up mainly of carbonate rocks (Dolostone and limestone), but there are alternative beds of shale and marl, with some sandstone wedges in the succession. Since the present study area was largely overlooked in earlier studies, an attempt has been made to exercise process-based sedimentological study in the area, to understand carbonate platform geometry. The facies types under this study are defined based on lithology, bed geometry, and sedimentary structures. From field-based facies identification and their respective petrography, seven different facies types were delineated that include six carbonate facies and one sandstone facies. From the wide variation in carbonate facies types viz. micritic, aspartic, bioclastic, and conglomeratic it is deciphered that the carbonates were deposited in a carbonate platform with distally steepened geometry. The presence of limited intraclasts conglomerate bears support in favor of this contention. Intermittent siliciclastic wedges within the carbonate succession are identified as input within the platform at times of high flood in distal delta or concomitant with tectonic pulses in the hinterland.

Keywords: Carbonate platform, Geometry, Devonian Hajigak Formation, Central Afghanistan, Facies analysis, Petrography

\section{Introduction:}

Modern sedimentology has evolved from grain- to basin-scale understanding in last six decades or so with introduction of two trend-setting concepts. The first breakthrough came with introduction of 'facies concept' in early seventies of last century (Middleton, 1973; Walker and Plint, 1992) that allowed appreciation of sedimentary units/structures in terms of their genesis i.e causative depositional/erosional processes. Field observations were ably backed by experimental set-ups in order to understand fluid-grain interaction, size effect on nature of interaction under flow shear, role of cohesion and relative roles of kinetic and gravitational energy in framing different sedimentary structures under lower (with Froud number $(\mathrm{F}=\mathrm{v} / \sqrt{\mathrm{gh}})<1)$ or upper $(\mathrm{F}=$ >1) flow regimes. Delineation of depositional agents, mutual association of agents in framing depositional architecture at different environmental settings, understanding controls of basinal (eustacy/tectonics) and out-of-basin (tectonics/climate) forcings on relative strengths of depositional agents, balance between basin accommodation and sediment availability and, finally, 
Developing a model that can explain all basin-scale features in a holistic space-time framework are goals of any present day sedimentological study leading to basin analysis. In last four decades, 'Facies model' turned up as a key concept in field-based sedimentological study as it allowed delineation of depositional agents and further, helped in understanding mutual association of agents in varying environmental settings. In addition, appreciation of facies succession allowed workers to exercise process-based paleo-environmental analysis.

In this backdrop, the present study attempts field and petrographic characterization of parts of the Devonian Hajigak Formation, Afghanistan in order to study its sedimentological build up, to throw some light on lithological variation in the study area and to underpin possible depositional process/es behind observed variations. Devonian succession, in particular, and Paleozoic succession, in general, from Iran, Afghanistan and Pakistan remained a topic of attention for workers for quite some time as it is believed that these successions can unveil depositional history at the northern margin of 'Gondwana' Supercontinent. Most of the studies, so far, dealt with faunal assemblage within these rocks and attempted correlation of successions exposed at different sections. Although correlatives of Devonian succession are described from both Iran and Pakistan, most extensive sites of Devonian rocks are documented from Afghanistan only and are being studied for last two decades. Under present study field work was carried out in Devonian succession of Hajigak Formation in roughly east-west transect, lithological variations were noted, lithologs were prepared and samples were collected for further laboratory studies.

\section{Locality of Hajigak}

Mountain Hajigak Mountain, which includes the present study area, is located in the South-East of Bamyan province and situated $130 \mathrm{Km}$ North-West of Kabul (Capital of Afghanistan) (Fig.1). It is one of the famous mountains in Afghanistan because of hosting huge iron ore deposits. Also, the mountain is located on the Herat Fault Zone that caused juxtaposition of different rock types of different ages, starting from Paleoproterozoic to Upper Devonian and Carboniferous rock. 


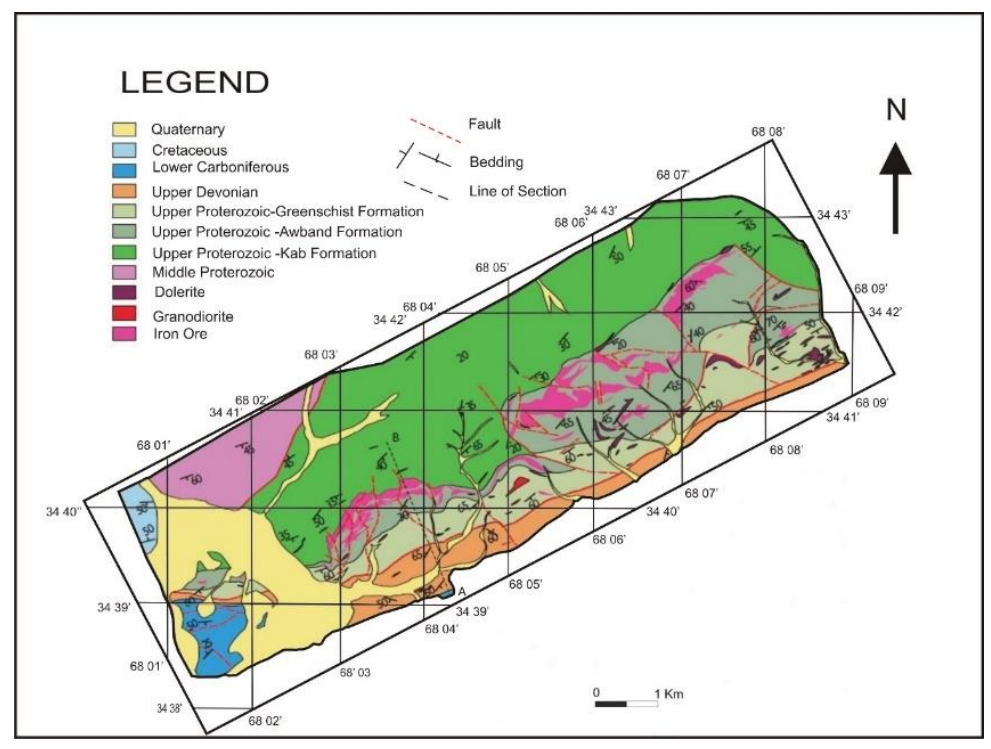

Fig.1.Geological Map of Hajigak Mountain

\subsection{General Geology and Tectonic Settings}

Afghanistan is a mountainous country with a very complex geology due to its position on the junction between the Indo-Pakistan and Asian crustal plates. The tectonic settings of Hajigak mountain, located on the Herat Fault zone is traced back to the accretion history of Gondwana supercontinent before becoming part of the Eurasian Plate margin. The accretionary event started 140 million years ago, and continued till recent. There are evidence of collision of Farad block with the Eurasian plate along Herat Fault zone. Later the Helmand Block collided with the Farad block. The rocks which are located in the Hajigak Mountains along the Herat Fault Zone are actually part of the Farad and Helmand Blocks.

The oldest of the succession crops out on the North-West of Hajigak Iron Ore Deposits. It consists of grey silicified limestone and dolomite interbedded with dark gray crystalline schists and light colored quartzites that shows the evidence of amphibolite grade metamorphism. The Hajigak iron ore deposit is hosted in the Upper Proterozoic Awband Formation that, together with the underlying Kab Formation, makes the Qala Series, a sequence of metavolcanic and metasedimentary rocks up to $4500 \mathrm{~m}$ thick. The Kab Formation consists of dark gray sandy sericiticschists, interpreted as metamorphosed terrigenous rocks, 
Acid volcanic rocks and minor beds of marble and phyllite. The Awband Formation consists of schists (quartz-sericite, quartz chlorite-sericite, quartz-sericite-chlorite and carbonaceous sericite) that are metamorphosed acid and basic tuffites, argillaceous rocks with minor cherts and marbles. Greenschist Formation which overlies the Awband Formation consists of green chlorite schists, and quartz-schists, locally intruded by granodiorites. Strata of lower Cretaceous and younger age crop out in the southwest of the area having unconformable relation with the older sequences.

The Upper Devonian rocks of the Hajigak Formation which is under the focus of present study unconformably overlies the Greenschist Formation. The predominant strike of the older rocks of Proterozoic and Paleozoics is between NE and NNE, with a regional dip of approximately $60^{0}$ towards south - southeast. The Upper Proterozoic rocks of the Qala Series area inferred as being deposited in a slowly subsiding marine basin. One major steeply dipping fault juxtaposed the Upper Proterozoic rocks against the crystalline middle Proterozoic rocks and threw Upper Devonian rocks against the Upper Proterozoic rock of Green Schist Formation, which stratigraphic viz. has been illustrated in Table.1.1.

As discussed in literature the initial filling of basin consists of variable sequences of sandstone and minor volcaniclastic sediments. Later on there was increase in the volcanic activity and exhalative iron rich fluids formed lenses on the sea floor. These sediments were subsequently altered by burial and low-grade metamorphism of green schist facies and made the basement of the Helmand Block. This block drifted away from Gondwana supercontinent in the Triassic, and during the collision with Eurasia, which has happened in the early Cretaceous, faulting juxtaposed the Upper Proterozoic Qala series, the Middle Proterozoic rocks and the Upper Paleozoic rocks, so that these fault bounded blocks are the local characterization of the Herat Fault Zone. As the collision developed, the faulted blocks were folded and disturbed in a Northeast -Southwest trending anticline, and the axis of this anticline passes from north of the area. During the final phase of faulting the north-south and north-west-south-east faults that affect the ore deposit were developed. Later on the post-Cretaceous extension led to the further progression of north-westsoutheast faults and graben structures filled with young sediments. 


\subsection{Earlier Studies on the Devonian Rocks in Afghanistan:}

The history of Devonian investigation in Afghanistan goes back as early as 1885 and continued till recent time. Several workers studied different localities of the country to find out the history of Devonian and to find mutual correlation between sections those are dissected by postdepositional fault systems. As per the published record the pioneering work on Paleozoic (Carboniferous) rocks exposed near Tagareh, Robat-e-Pai area, located in the Band-e-Bayan, also called the Axial Zone which was described by Griesback (1885, 1887 a,b).

Subsequently, Hayden $(1909,1911)$ described the Devonian outcrops in the Hajigak area, which is also located in the Band-e-Bayan. However, the most important and numerous Afghanistan Devonian outcrops, are located in Central Mountain "Hazarajat Mountains", which have only been discovered recently. Martina in 1963 has discussed a possible Devonian age for the Hajigak limestone. Hinze in 1964 concluded Devonian age for the" Hajigak Limestones and Haematite", and also provided a detailed description about the Hajigak section recognized by Hayden. Devonian outcrops in Hazarajat "Central Mountain's" were discovered for the first time by Durkoop, A., Mensink, H. and Plodowski, G., 1967.

With these publications and discoveries it was concluded that the upper Devonian rocks was recognized by Hayden in 1911, Lapparent in 1963 and 1964. Mistiaen et al (2015) concluded that the Devonian succession present in the eastern and central parts of the Band-e Bayan belongs exclusively to Upper Devonian (Frasnian and Famennian) and suggested that as a consequence, the stratigraphic successions in the area is considered as recording only the transgression of discordant Upper Devonian (Frasnian) on older rocks, with a significant break between the lower Paleozoic and Upper Devonian.

\begin{tabular}{|c|c|c|}
\hline \multicolumn{2}{|c|}{ HAJIGAK MOUNTAIN LITHOSTRATIGRAPHIC SUCCESSION } \\
\hline Age & Thickness & Name of the Formation \\
\hline Post Jurassic Cover & $>600 \mathrm{~m}$ & $\begin{array}{r}\text { Cretaceous, Neogene, and Quaternary } \\
\text { soil cover }\end{array}$ \\
\hline Upper Carboniferous & $>2500 \mathrm{~m}$ & $\begin{array}{c}\text { Kharzar Formation } \\
\text { Pelitic-schists, Quartz rich schists, } \\
\text { sandstones, quartzites, and conglomerates }\end{array}$ \\
\hline
\end{tabular}


Publication Date: 5-11-2021 ISSN: 2706-6495

\begin{tabular}{|c|c|c|}
\hline \multirow{2}{*}{ Upper Devonian } & $>900 \mathrm{~m}$ & $\begin{array}{c}\text { Hajigak Formation } \\
\text { Limestones, sandstones, shales, } \\
\text { conglomerates, and pellitic-schists }\end{array}$ \\
\hline \multirow{2}{*}{$700 \mathrm{~m}$} & $\begin{array}{c}\text { Green Schist Formation } \\
\text { Quartz-chlorite-Sericitic schist, Quartz- } \\
\text { chlorite shcists, and gabbroic intrusive }\end{array}$ \\
\cline { 2 - 3 } & \multirow{2}{*}{300 to $1000 \mathrm{~m}$} & $\begin{array}{c}\text { Quartz-sericitic schist, chlorite-sericitic- } \\
\text { shcists, marbles, quartzites, extrusives, } \\
\text { lenses of iron ore }\end{array}$ \\
\cline { 2 - 3 } & \multirow{2}{*}{$3500 \mathrm{~m}$} & $\begin{array}{c}\text { Kab Formation } \\
\text { Quartz-sericitic schist, Phyllites, marble, } \\
\text { altered extusives, and lenses of iron ore }\end{array}$ \\
\cline { 2 - 3 } & \multirow{2}{*}{ Middle Proterozoic } & $\begin{array}{r}\text { Jawqul Formation } \\
\text { Crystalline schists, quartzites, silicified } \\
\text { limestones, and dolomites. }\end{array}$ \\
\hline
\end{tabular}

Table.1.1. Lithostratigraphic succession of Hajigak Mountain of Afghanistan

\subsection{Knowledge Gap}

It is apparent from literature that Devonian rocks of the Hajigak Formation is being only worked upon for their paleontological criteria correlation with other Devonian rocks exposed all over Afghanistan. Attempts have also been made to identify tectonic events related to the mountain building and their effects on the lithology and structure of the area. But, no study is available in literature related to facies and paleo-environment vis-a-vis, analysis of sedimentary processes involving grain size analysis, modal analysis, detailed petrography and etc., the present dissertation work thus attempts description of lithology, facies types, sediment petrography including modal analysis and inference of possible paleo-environmental conditions.

\subsection{Objectives of Present Work}

1. Field-based documentation of lithological variations in basal $100 \mathrm{~m}$ succession of Hajigak Formation; reconstruction of facies succession development by detailed litholog preparation at four different sections over an east -west stretch of $3 \mathrm{~km}$. 
2. Collection of samples from different lithological entities encountered; petrological observations and interpretations

3. Correlation of facies lithologs measured at different localities based on petrology and field based data.

4. To propose a tentative depositional setting within limited observation.

\section{Facieses analysis}

Process based facies analysis in any sedimentary succession depends heavily on identification of physical, chemical, and biological characters of a litho-unit, which is distinct from its adjacent litho-unit. In normal sedimentological parlance delineation of such distinctive lithesome is termed as "facies" (Driese et al., 1984; Walker, 1986; Reading 1986). Documentation of facies constitutes the primary goal in order to build up a story of paleo-environmental setup of any sedimentary basin (Boggs, 2006; Posamentier and Walker,2006). However, the application mode of facies concept is different for siliciclastic and carbonate sedimentary successions; while in siliciclastic settings workers rely on lithology including granulometry, i.e. grain size, sorting, etc. and other similar physical aspects of litho unit, in case of carbonates, particularly those of fine grained variety, dependency become more on microscope, rather than field-centric. However, features like bed geometry, sedimentary structure, and type of fossil present play important role in facies delineation from either of these settings.

The Hajigak Formation overlies the Greenschist Formation and is being made up mainly of carbonate rocks (dolostone and limestone), but there are alternative beds of shale and marl, with some sandstone wedges in the succession. Since the present study area was largely overlooked in earlier studies, attempt has been made to exercise process-based sedimentological study in the area so as to understand geological buildup of the area. The facies types under this study are defined on the basis of lithology, bed geometry and sedimentary structures. The facies are described below.

\section{Basement for the study section}

Fine-grained chlorite-sericite schist constitute basement for the study section (Fig. 3.1). Rocks in the basement, in general, characterized by dark green to grayish color, occasionally become reddish when host iron ore. 
The rock strata displays gentle folding and well defined schistosity. Schistosity surfaces are few millimeters to $10 \mathrm{~s}$ of centimeter and overall these schists record low to intermediate grades of metamorphism. The foliation surfaces trend NE $-\mathrm{SW}$ and dip towards SE..

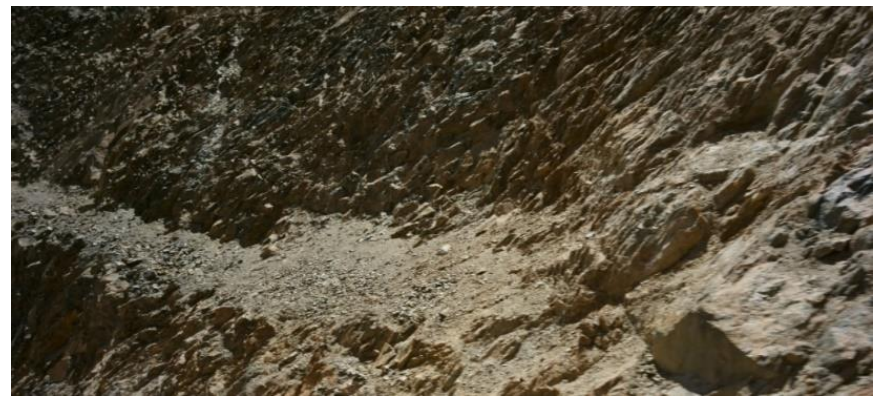

Fig.3.1.Well foliated chlorite-sericite-shchists

\subsection{Facies types; their description and genesis}

\section{Limestone Facies}

\section{Facies A}

This facies is made up of dark color micritic limestone with some occasional extra clasts in it (Fig. 3.2). In field the facies reveals massive character without any clear bedding structure. It was not possible to decipher anything about this facies with naked eye in field. Mostly this facies is restricted in the basal of study section and maximum thickness recorded is $18 \mathrm{~m}$. Extraclasts present in this facies are very less in abundance and whenever present made of calcareous mudstone.

Dark colour, dominant micritic nature and overall massive character bear indication of very low energy deposition of this facies (NP.James, 1977).

Extra clasts in such low-energy domain bear indication of rare supply from some slope failure (Bose and Sarkar, 1992). However, allogenic contribution always remained limited.

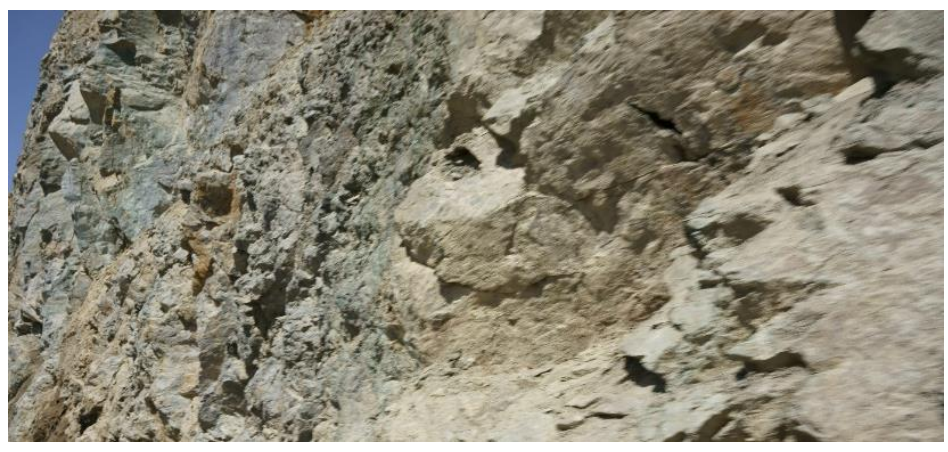

Fig.3.2. dark colored micritic limestone of facies A 


\section{Facies B}

This facies is made up of fine grained, thinly bedded shales of yellowish to white grayish color, often with limestone interbeds with varying bed thickness. In fact, the facies is seen repeatedly in the study area with varied expression. At times this facies is without any limestone interbed, sometimes with few cm. to decimeter thick limestone interbed (Fig. 3.3) and at cases interbedded with coarse-grained limestone wackestone/packstone (Fig. 3.4). In one section, grain size at the basal part of the facies is dominantly clayey and muddy, whereas it becomes more sandy and granular at the upper part. The facies at this section is subdivided into two parts viz. lower and upper. While in the lower part it is represented by very find-grained shale occasionally black in colour, in the upper part shales are found interbedded with dolomite and conglomerates (wackestone to packstone) in varied proportion. When checked with dilute $\mathrm{HCl}$, shales also found to be calcareous. At cases the limestone interbeds are found to be marly.

This shale facies possibly represent deposition over a reasonably varying energy domain varying between very low energy to intermediate/high energy where it interfingers with carbonate wackestone/packstone. The intermediate energy is reflected when thin bedded limestones alternate with shales.
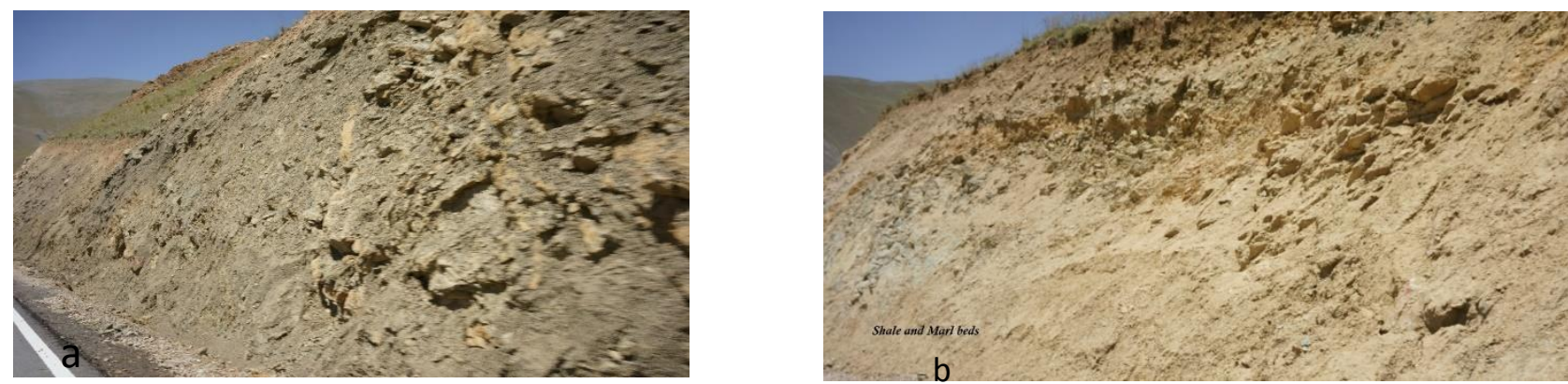

Fig.3.3. (a) shale plane laminated beds, and limy and sandy shales, (b) Shale interbedded with carbonate wackestone/packstone (arrowed)

\section{Crystalline massive/ bedded Limestone}

Two facies variants under this category are noticed in the study area viz. Bedded Limestone and domal, lensoidal crystalline dolostone. 


\section{Facies C: Bedded limestone}

This facies consists of bedded limestones of different thicknesses, whitish, grayish and brownish in colour and with some degrees of gentle folding. Maximum thickness of this facies is $75 \mathrm{~m}$ and exposure of this facies is encountered in association with facies D. Alternation between thin and medium bedded limestones constitutes the basic motif of this facies (fig. 3.5). The beds are having thickness of averaging 2-10 cm and are sheet like in geometry with sharp lower boundary and sharp to gradational upper boundary and internally massive or plane laminated. Bedding character in this facies widely variable; ranging from irregular and laterally inconsistent to laterally consistent and thereby attaining well-defined sheet geometry (Fig. 3.6) there is no grain size variation visible within bed. Under microscope this facies is showing micritic limestone, with some bioclast in it.
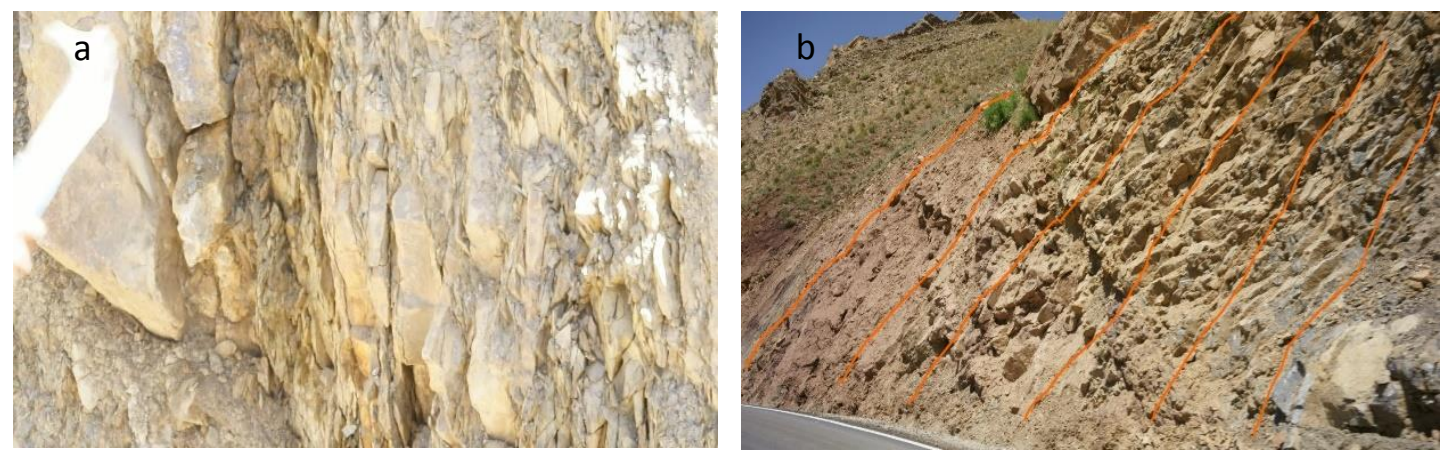

Fig.3.5. (a) thin and medium beds of limestones. Note irregular bed geometry. (b) Thinly bedded sheet-like character of facies $\mathrm{C}$ limestone.

\section{Facies D: Domal, irregularly, bedded dolostone}

Sandwiched between facies B and E (discussed later) on one side and facies $\mathrm{C}$ on the other side, this facies consists of coarsely crystalline dolostone (Fig. 3.7) and some alteration with dark brown color limestone. With a general massive look, this facies shows a very coarsely crystalline character under microscope and hence, named as crystalline dolostone, making $\sim 52 \mathrm{~m}$ of the whole succession. Best development of this facies is noticed in traverse I. 


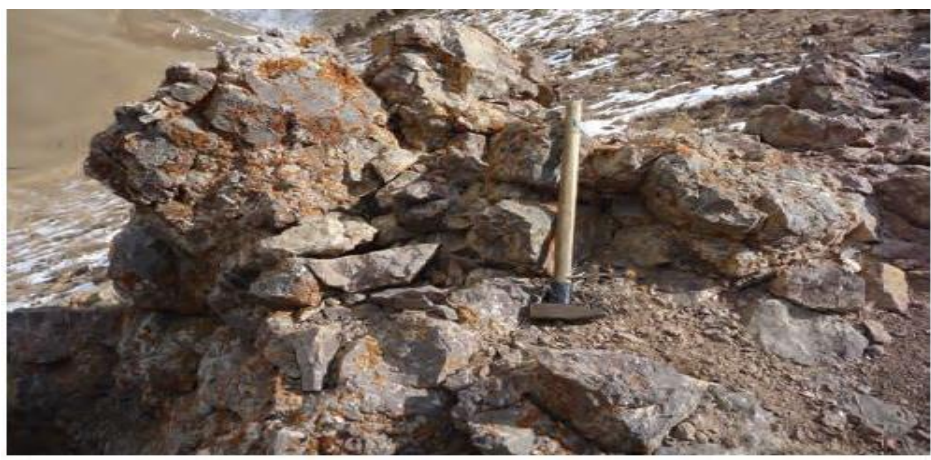

Fig. 3.7. Domal crystalline dolostone

\section{Facies E:}

This facies, is closely associated with facies D, which is made up of brownish color fossiliferous limestone with subordinate shale. Examination of shales reveal presence of macrofossils including fragments of bioclasts of brachiopods, corals, and micro-fossils of gastropods, bivalves, and shells of corals etc. The matrix is made up of micrite and sparite with some crystals of calcite and dolomite. The characteristics of lithology is having varying grain sizes i.e. shales are of fine grained clay size, and limestones are coarse grain in the ground mass, together making about $100 \mathrm{~m}$ of this lithology, which is being shown in fig.3.8.

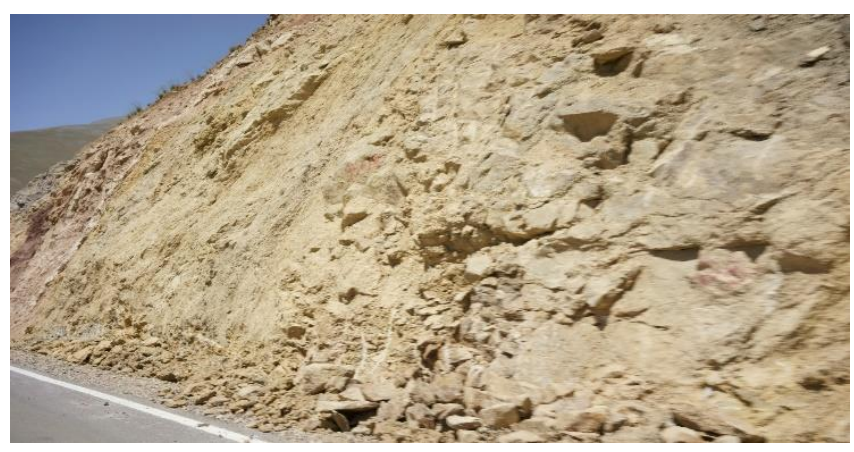

Fig.3.8 Brownish color limestones of fossilefirous and shales of fossil contained in it

\section{Facies}

This facies consists of medium to coarse grained lime conglomerates (Fig. 3.9). Exposures of this facies is traced about a few meters contiguous to facies D and E. Internally, this facies is made up of lime clasts of pebble to cobble size ranging between $5 \mathrm{~mm}$ to $7 \mathrm{~cm}$ in diameter set in ground mass of fine to coarse grains limestone.

Occasionally a few siliciclastic boulder and granule also observed. Laterally away from facies D and $\mathrm{E}$ this facies unit wedges out. 

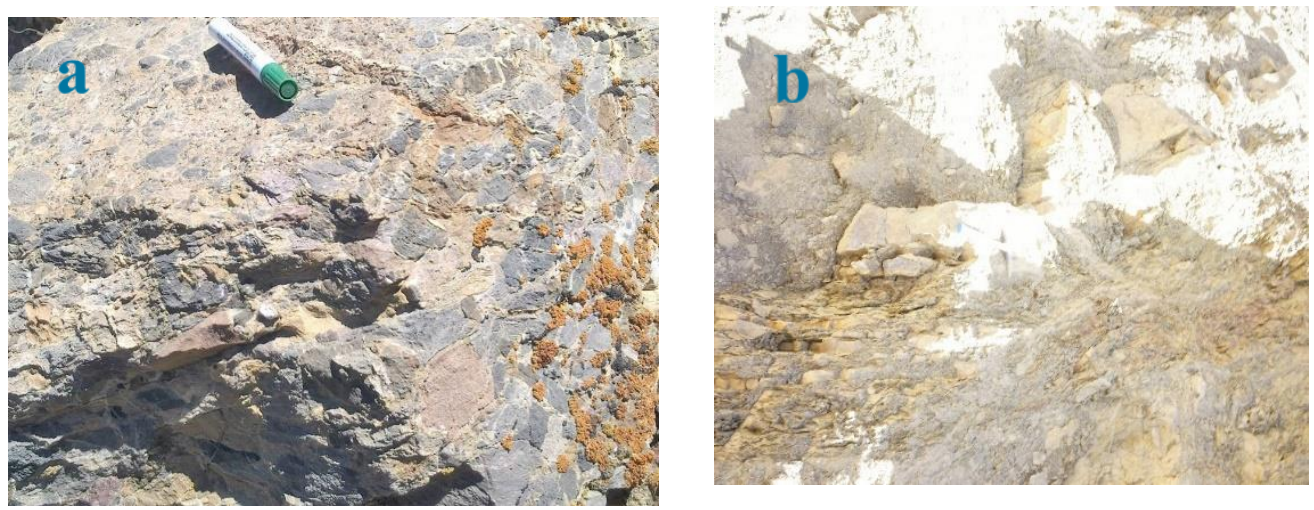

Fig.3.9 (a,b). Conglomerate with varying grain sizes

Overall, the facies unit show a fining upward character with clast size decreasing upward. Lateral impersistence and absence at certain sections are hallmark characters for this facies.

\subsection{Sandstone Facies: Facies G}

This facies unit is cms to decimeter thick, wedge shaped in geometry, recurrent in occurrence and consists of very fine grained arkosic sandstone, dark in color (Fig. 3.10). No sedimentary structure is visible and hence, massive in character. Grain size shows discernible variation from base to top and the sandstone units, in general, show fining- upward character. The facies unit makes some 20 meters in some localities but it is not continuous and laterally pinches away. In studied sections occurrence of this facies unit has been encountered at two stratigraphic levels.

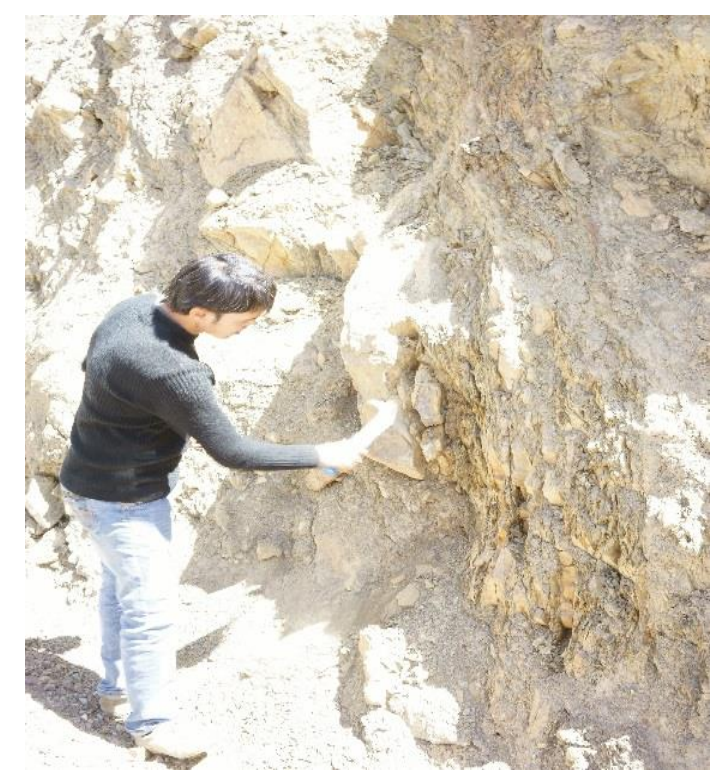

Fig.3.10. Fine grained arkosic sandstone of facies G 


\section{Basement:}

As discussed in chapter 3, the basement for Hajigak Formation is a foliated greenschist rock. Under microscope the greenschist rocks are found to be made up of chlorite and sericite with moderatelydeveloped schistosity. Mineral assemblage is represented by chlorite, sericite, quartz, opaque minerals with some amount of iron oxide (Fig.4.1.a, b). In western part of the study area i.e at section IV basement shows relatively low grade metamorphism with well-developed foliation and lineation. Association of basement with carbonate and patches of opaque minerals can also be seen. Fine grained iron oxide is identifiable as opaque mineral along with some grains of quartz (chert), chlorite and other opaque minerals. In some thin section development of eye shape structures is noticed (Fig. 4.1.c and d).
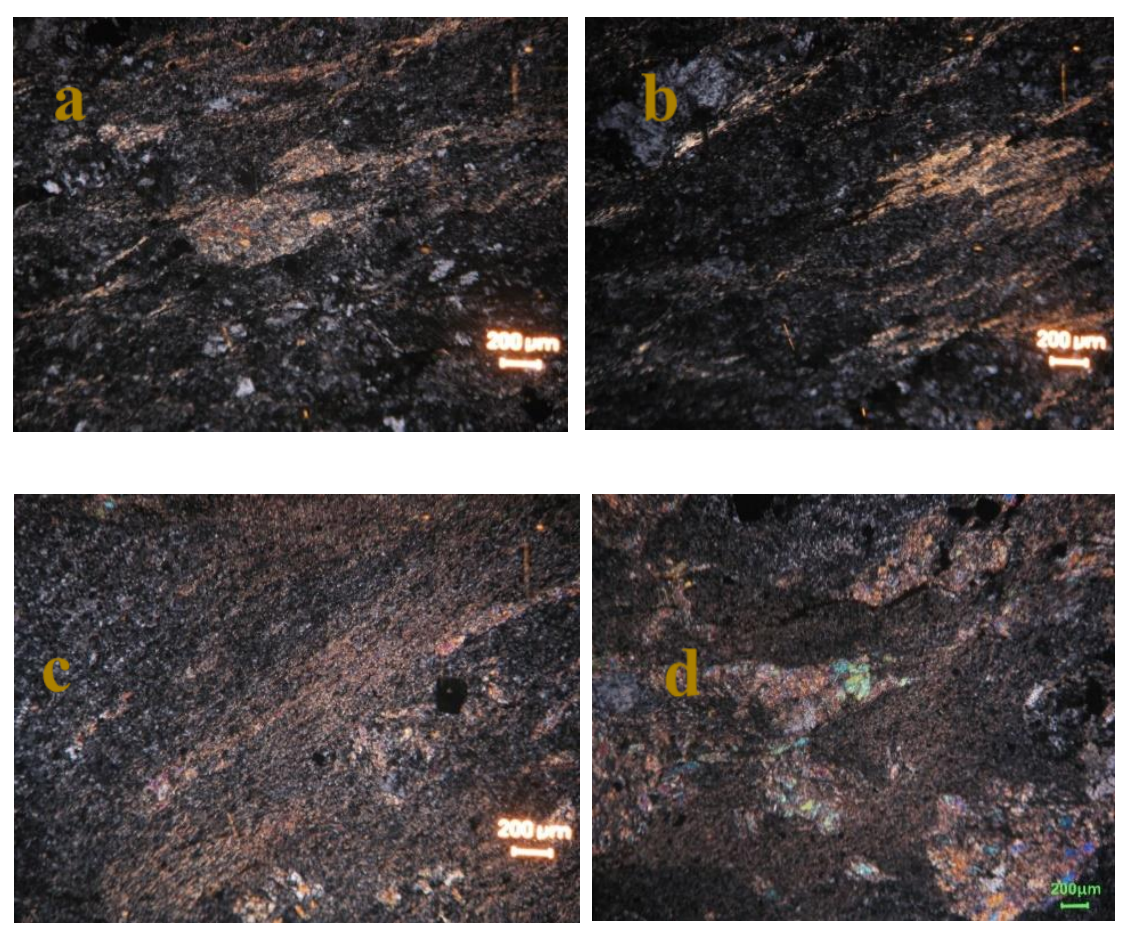

Fig.4.1 (a, b, c and d) Petrography of greenschist rocks forming basement for the Hajigak Formation

\subsection{Carbonates:}

As discussed, carbonates encountered all through the studied succession; the main lithology of Hajigak formation is made up of limestone and dolostone. For petrography samples were systematically collected from all carbonate facies types delineated under field study. 
In total, nineteen samples were collected from different facies types of carbonate and observed under microscope by making thin sections. Broadly, carbonates vary from micritic to varied orders of recrystallized sparite; signatures of secondary chertification also seen in some facies types. A detail description of different petrographic varieties of carbonate is given below. Petrographically, the Hajigak Formation carbonates are classified under following categories.

4.1.1. Fully crystallized carbonate made up of sparry calcites,

4.1.2. Incompletely crystallized carbonates,

4.1.3. Chertified limestones, and admixtures of carbonate and siliceous composites,

4.1.4. Fossiliferous limestone with micro-fossil,

4.1.5. Extra and bioclasts embedded within micritic ground mass,

4.1.6. Very fine grained volcaniclastics and siliciclastics admixtured with limestone

\subsubsection{Fully crystallized carbonate made up of spar cements}

Carbonates of facies $\mathrm{F}$ and $\mathrm{E}$ under microscope reveal coarse crystalline character with well-developed spars having two sets of calcite twins. Depending upon orientation of calcite crystal one and two sets of twining are observed, and under PPL carbonates show brownish white to pinkish colour. Most of the grains are sparite, and often fractures are filled with iron oxide. At cases growth of spar grains are found incomplete and concomitant presence of micrite and sparite can be seen. Two colour shades are seen in these carbonates in PPL viz. white and yellowish, which has been shown in fig.4.2a,b,c and d.
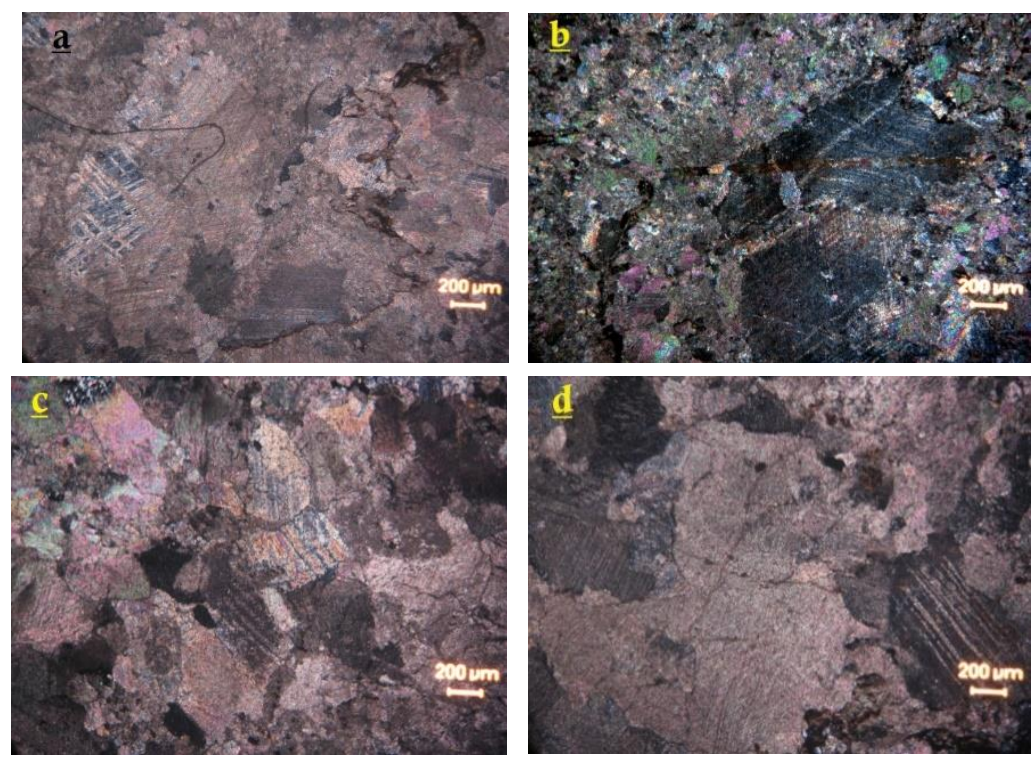
Fig. 4.2(a).Fully recrystallized carbonate made up of sparry calcite. (b). Incomplete recrystallization micrite changing to sparite. $(\mathrm{c}, \mathrm{d})$. which is making the middle part of section I and basal part of section IV

\subsubsection{Incomplete recrystallized carbonate with equal proportion of micrite and spar}

Rocks of facies $\mathrm{C}$ under microscope show incomplete crystallization i.e. both micrite and sparite coexist in varying proportion (Fig. 4.3.). Often inclusions of micrite can be seen within spar grains. Also, stringers and patches of micrite are observed between growing microspar grains. While micrites are very fine grained and relatively dark in appearance, neospars are whitish, clear in occurrence. However, well defined calcite crystal is rare amongst the neospars.

Neomorphism, i.e. transition from micrite to sparite, is clearly observed in these rocks. Presence of both micrite and spar reflects incomplete recrystallization.

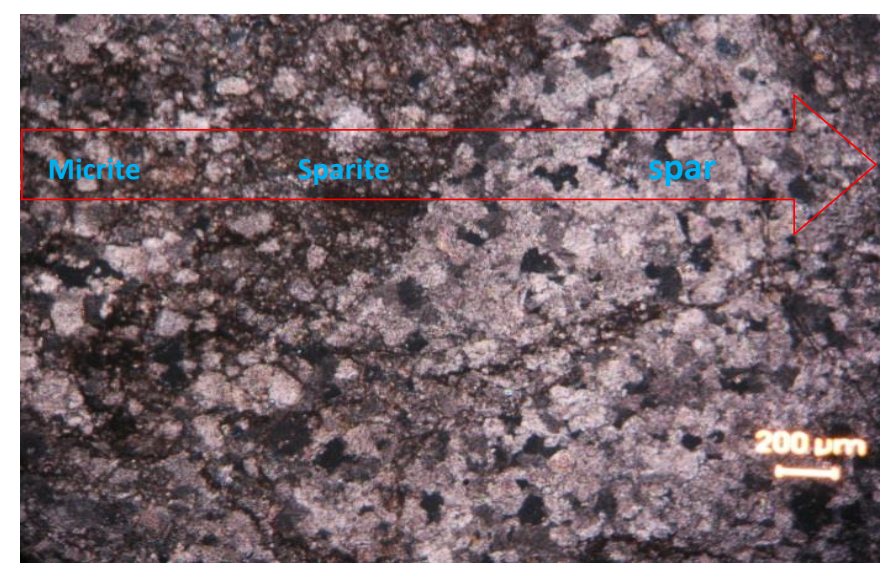

Fig. 4.3. Incomplete recrystallization of carbonate rocks .

\subsubsection{Chertified carbonates:}

This petrographic facies (silicified micrite/sparite) also corresponds to the rocks of facies D and E. Microcrystalline quartz in form of chert is present replacing carbonates as secondary diagenetic mineral (Fig. 4.4.a, b). At cases, silica replacement of carbonate minerals is seen along some fracture or bedding plane. These weak zones act as conduit for silica rich fluid and prompt precipitation of microcrystalline silica. At times, both micrite and spar are replaced by silica (Fig. $4.4 \mathrm{c}, \mathrm{d})$. 

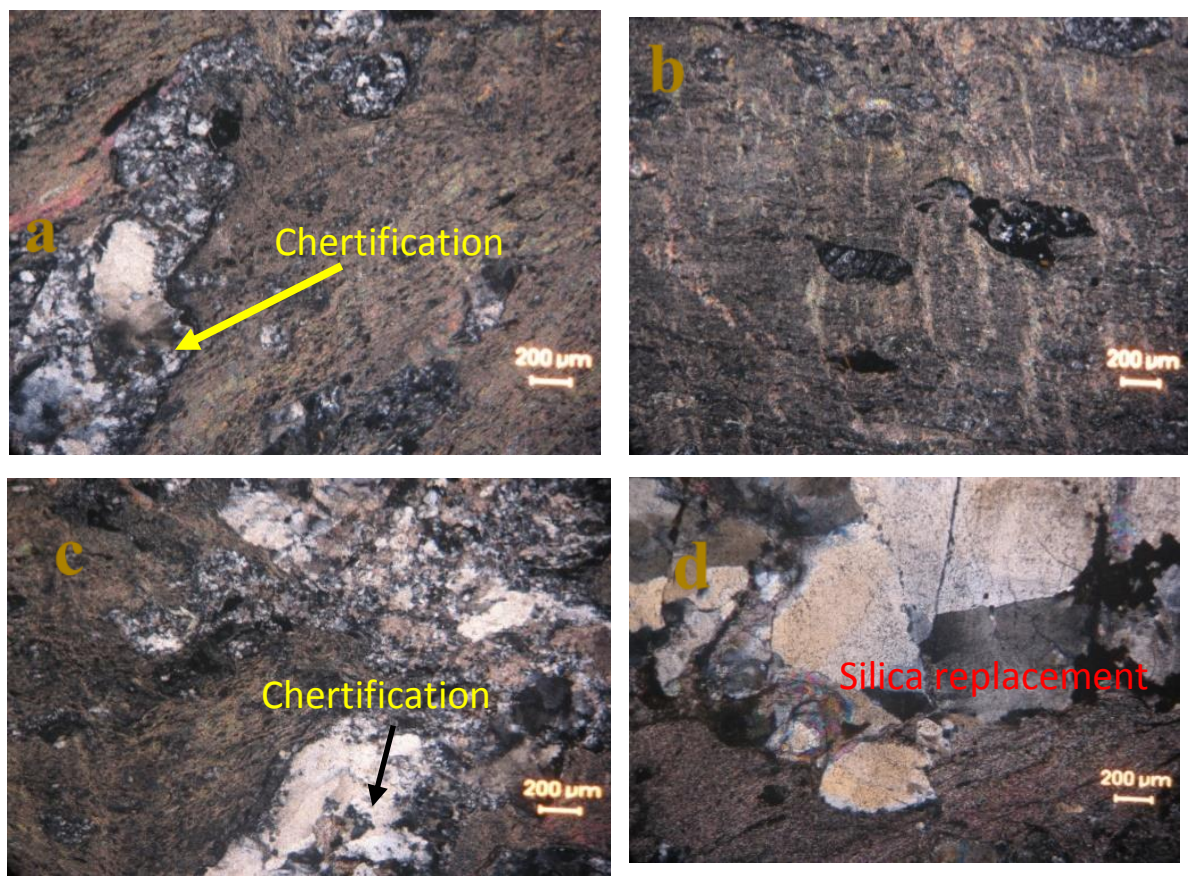

Fig. 4.4.a, b, c, d. are showing a chertified character of the rock types in transition zones

\subsubsection{Fossiliferous carbonate limestones with different micro-fossils:}

This petrographic facies (biomicrite to biosparite after Folk (1959) belongs to facies types C, D and $\mathrm{E}$ whenever degree of recrystallization is low. Best representation of the fossiliferous part of carbonate rocks can be found at the middle part of studied succession with varying types of microfossils and fossil fragments such as bivalves, foraminifera, coral fragment, bryozoa, shells of different micro-organisms and gastropods (Fig. 4.5a). The bioclasts also include different macro-fossils such as brachiopods (Fig. 4.5b, c) and some other types of upper Devonian fossils. Fragmented brachiopod shell clasts are found in abundance. In some samples from facies D and E presence of oolite (Fig. 4.5d) is also noticed. Record any preferred orientation of allochems; rather random distribution is the character of studied thin sections. None of the thin sections are showing same characters, so that the ground mass varies from micritic to sparitic. 

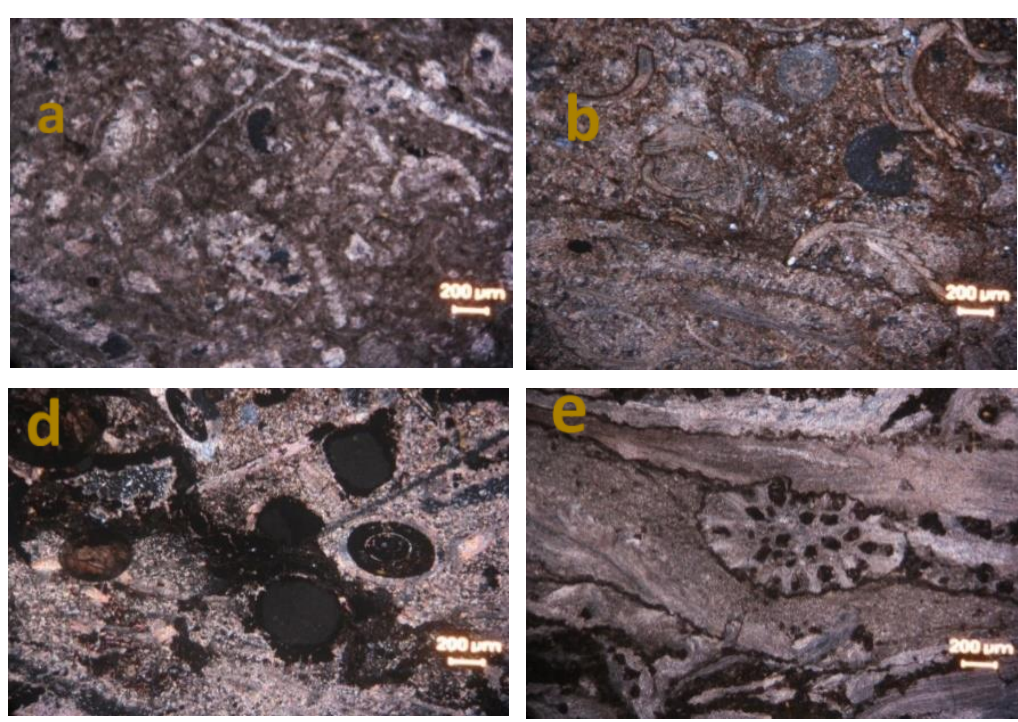
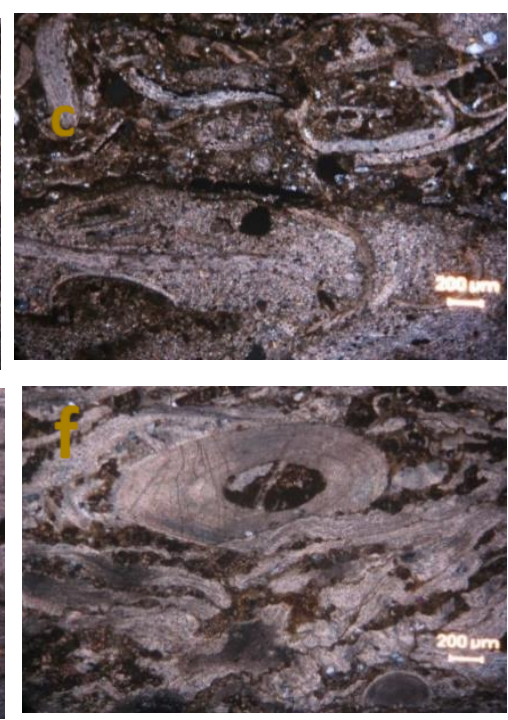

Fig. 4.5. (a,b,c,d,e,f) are showing the fossiliferous limestones in the succession

\subsubsection{Extra- and bioclasts embedded within micritic groundmass:}

Rocks of facies A and carbonate interbeds within facies B show this petrographic character. Carbonates of this facies have very fine grain (micrite) groundmass with isolated extra clasts embedded within micritic matrix (Fig. 4.6.b). Rocks are orthochem (matrix) supported, only rare bioclasts, and extraclasts bear coarse grain sizes of very coarse (Fig. 4.6a). Also, cavities and pores within bioclasts are filled with micrite. On the bases of the above composition rocks of this facies are named as micritic limestone.
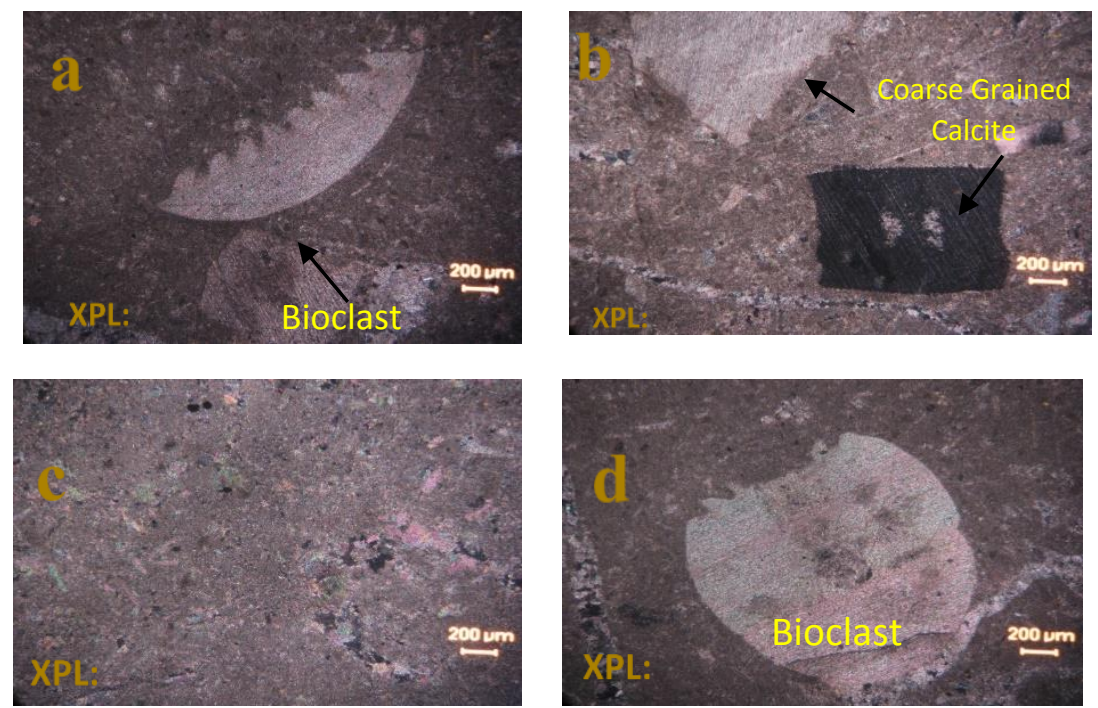

Fig.4.6.(a, b, c, and d) micritic limestone, with extraclasts and bioclast embedded in it. 


\subsubsection{Very fine grained volcaniclastics admixtured with limestone and other minerals:}

Some thin sections of facies $\mathrm{E}$ and $\mathrm{F}$ show this petrographic character. These samples in hand specimen show very dark color and under microscope show very fine grained nature. Mineralogically these rocks are made up of albite, quartz, opaque mineral (Fig. 4.7.a,b); welldeveloped plagioclase microlaths are visible in certain thin sections (Fig. 4.7.c,d). In general, the rocks are moderate to well sorted, highly fractured and brecciated, character of groundmass varies between calcareous to silicic.
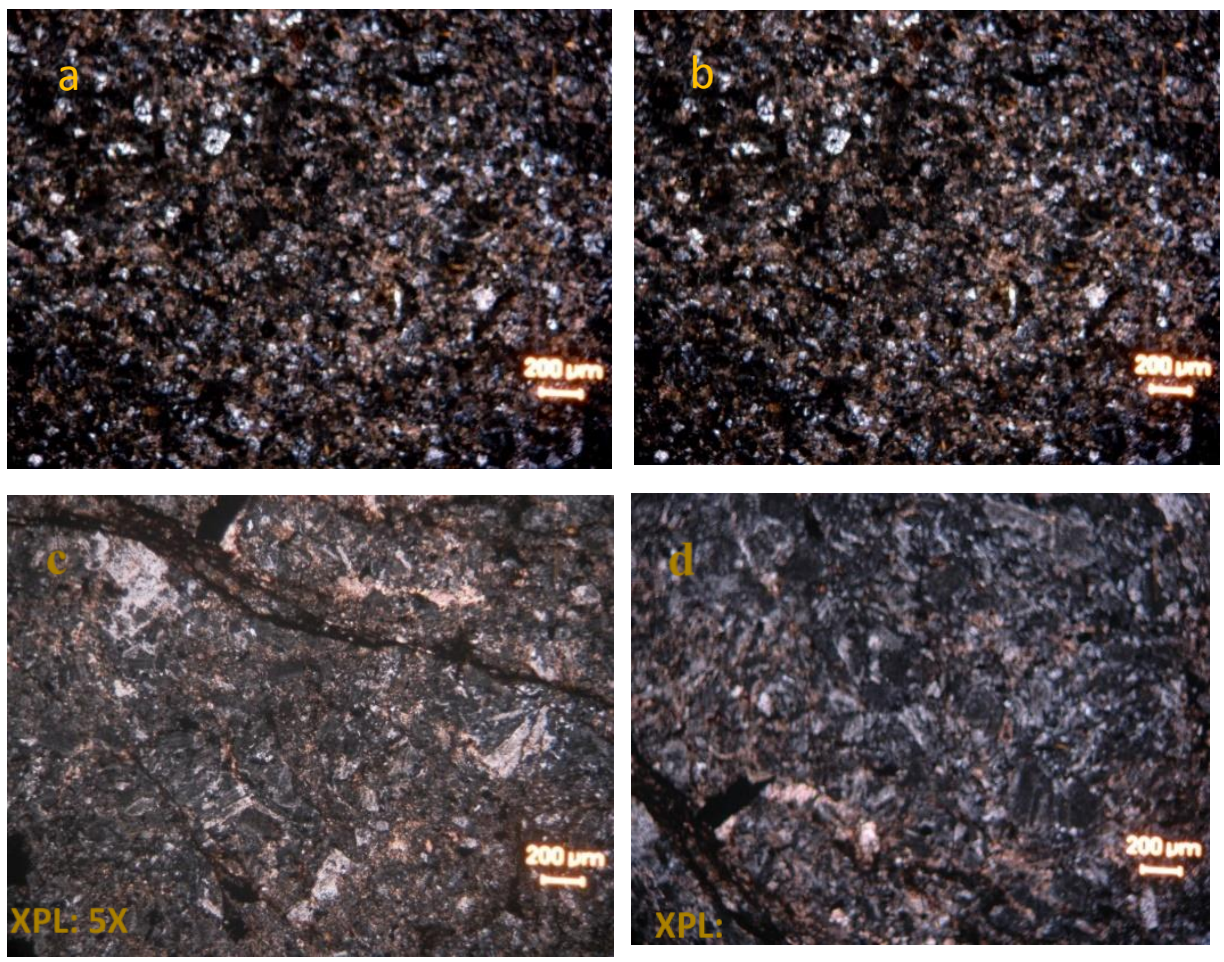

Fig. 4.7.(a,b,c,d) Fine grained volcaniclastic rock

\subsection{Siliciclastic Rock Petrography:}

As already discussed there are some sandstone wedges those punctuate the carbonate succession in the studied section. None of these sandstone wedges could be traced for more than a $\mathrm{km}$. Two most prominent ones are encountered in the lower and upper part of succession. Petrography of the sandstone wedges reveals their widely varied character 
4.2.1. Fine grained arkosic sandstone with high percentage of weathered feldspar,

4.2.2. Coarse grained arkosic sandstone with poor sorting and low percentage of weathered k-feldspar, but high percentage of crystalline fresh feldspars

4.2.3. Fine grained sandstone with low percentage of feldspar and high amount of quartz

\subsubsection{Fine grained arkosic sandstone with high percentage of weathered feldspar,}

The petrography of basal most sandstone wedge reveals high percentage of weathered feldspar and fragments of greenschist as framework elements (Fig. 4.8.a, b). The other framework grains include quartz grains mostly sub-rounded to well-rounded, at times polycrystalline in nature. Sorting of grains moderate to well with clayey matrix present within framework though the rock overall show grain supported fabric. Decomposition of Kfeldspar to generate clayey matrix (pseudomatrix) can be observed.
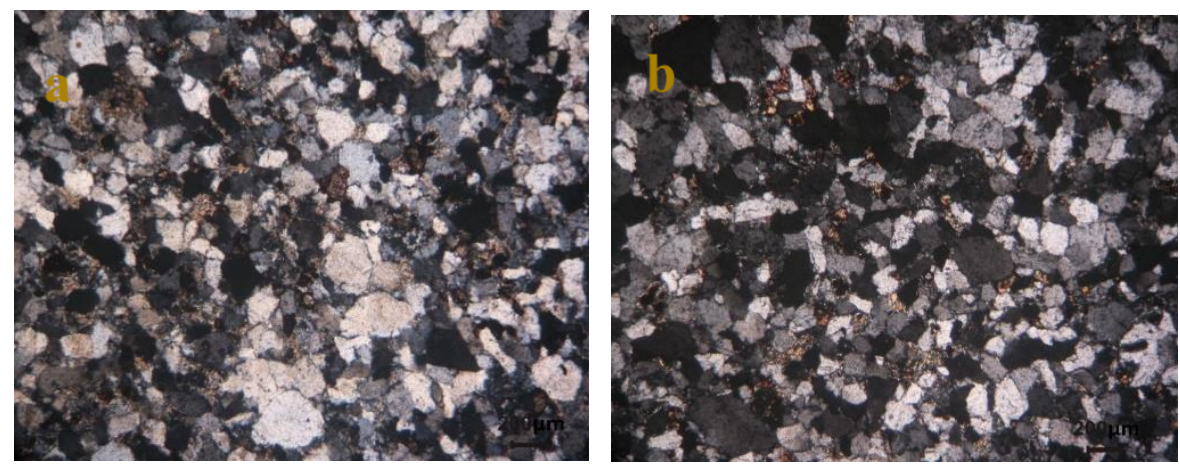

Fig.4.8.a, b. siliciclastic sandstone with high percentage of weathered feldspar.

\subsubsection{Coarse grained arkosic sandstone with poorly sorting}

Up the succession grain size in the sandstone wedge become coarser; vary between coarse to very coarse sand size with high percentage of feldspar grains (Fig. 4.9.a, b). Unlike the earlier wedge, feldspars are not much weathered. The rock is poorly sorted and percentage of rock fragment is much low compared to the basal wedge. Grains are moderate to high angular and presence of sweeping extinction can be observed in most grains. Sorting of grains is very poor as it is in other wedges. 
Quartz content is low and when present are of both mono- and polycrystalline variety. Polycrystalline grains often show sub-grains with some definite orientation indicating their derivation from some metamorphic sources.
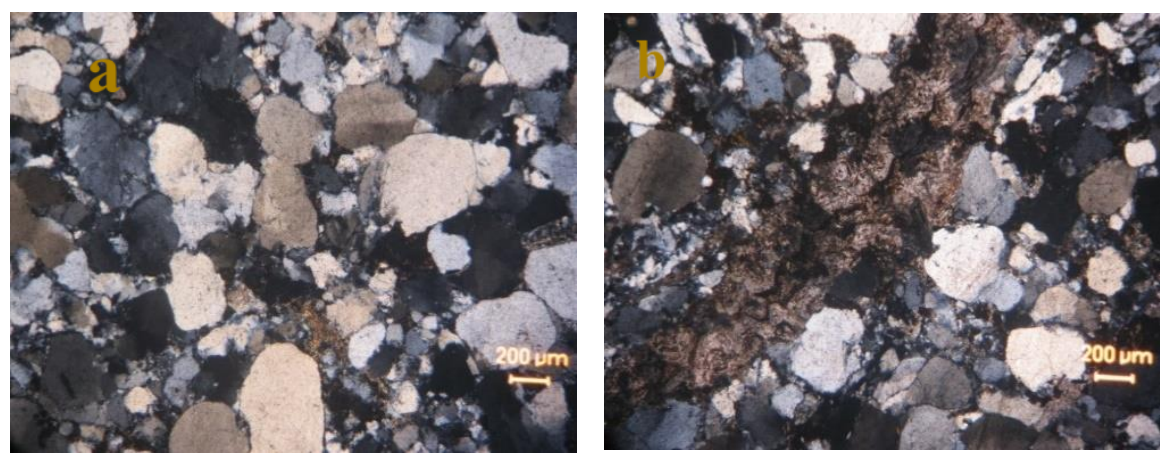

Fig. 4.9.a, b. arkosic sandstone in the middle wedge of Hajigak Formation

\subsubsection{Fine grained sandstone with low percentage of feldspar, but high quartz}

Upward feldspar content decreased in the wedge. A sandstone wedge present at the upper part of succession in section II shows different petrographic character compared to the other ones with higher percentage of fine grained quartz. Grains in this wedge is relatively well sorted, coarse silt to fine sand size and represented by quartz, mostly mono-crystalline, minor feldspar and some opaques set in clast-supported fabric with minor $(<7.5 \%)$ clayey matric mostly epimatrix in origin. Cement content is very low but mostly represented by silica overgrowth. The rock is identified as arenite fig. $4.10 \mathrm{a}, \mathrm{b}$.
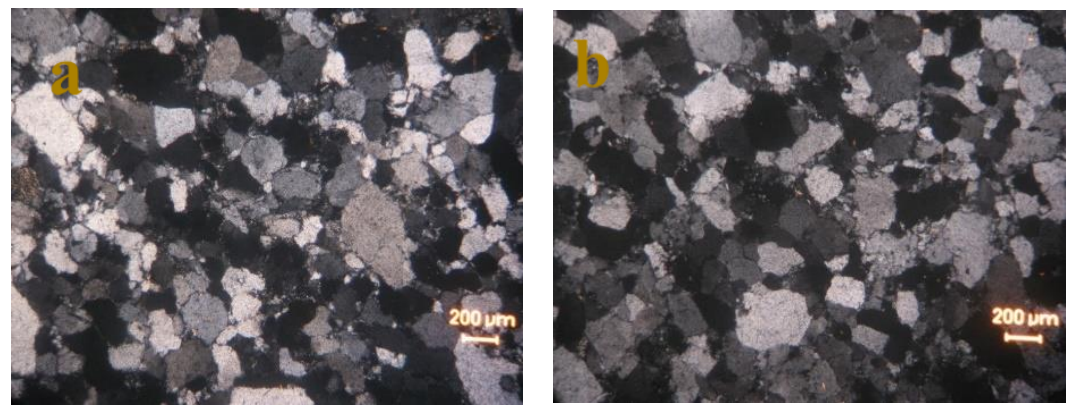

Fig.4.10.a, b. section II, fine-grained sandstone well sorted. 


\section{Discussion and Conclusion:}

The Devonian of Hajigak Formation represents an important interval in Afghanistan Geology. Despite attention of geologists around the globe, the formation remained largely unattended in terms of its sedimentation history, as well as its build up as a carbonate platform. Within limited scope of study, the present work aims at understanding genesis of different carbonate litho-assemblages, and further assimilate these in terms of a possible carbonate geometry platform, process based facies analysis and facies specific petrography helped in this endeavor.

Based at bedding geology, lithology, and mutual association of facies types the study area has been modeled as a distally steepened ramp. In a seminal paper, Read (1975) described different geometry of carbonate platform, and classified those in two broad categories viz. ramp and rimmed shelf. These two broad varieties widely differ in their facies distribution and spatial energy variation. A major difference between the two types is in the presence of carbonate mass flows; while rimmed shelves triggered generation of mass flows, the ramps, except for distally steepened once, do not show presence of significant mass flow. Unlike rimmed shelf the distal steepened ramps do not encourage formation of wave baffling reefs.

Reefs forms in distal steepened ramps are mostly patchy and triggered by intra basinal tectonics that makes basin flowed shallow bringing it within light penetrating domain. Mass flow generated from these small scale reefs are aerially restricted and small scale in occurrence.

In the area under study the domal bioclastic limestones of facies D and E are interpreted as possible patch reef in the Hajigak Formation carbonate platform. The reworked shelf clasts, oolites and broken fragments of macro and micro fossils bear tell-tale signature for wave remarking operative during formation of these facies limestone -conglomerate (Facies F) immediately superjacent to Facies D and E suggest derivation of small scale mass flows from the reefs and wave action bedded limestones of (Facies C), irregular or even in character are identified as Leeward deposition on the basin side of these patchy reefs. Absence of any current wave feature suggest their deposition in a subtidal setting below Fair Weather Wave Base (FWWB). 
Facies types on the wind ward side of patch reefs were essentially of very low energy micritic limestone (Facies A), limestone-shale alteration (Facies B), are identified as product of sedimentation on the ramp flat wind ward part of reef. Perhaps the physiography of the ramps was irregular generating such ponding effects cause variation in facies distribution either in terms of micritic limestone (Facies A) or limestone - shale alteration (Facies B).

In fig.5.1. a cartoon model illustrates possible geometry of Hajigak ramp system that cannot be deciphered from the present study. A close look of the figure clearly shows variation in facies pattern on the windward and lee ward side of possible reef. Despite being a low gradient system developed at a shoal structure cause differentiation in facies pattern on the ramp and thereby caused a wide variation of carbonate lithology in the study area.

In these back drop, occurrence of sandstone wedges at different stratigraphic levels within the studied section bar testimony to supply from distant delta either because of high energy discharge event or because of tectonic trigger. Wedge like geometry and high feldspar content (20 $-28 \%$ Feldspar), in wedges at the basal part of the section prompt interpretation of tectonic switch behind supply of these wedges. Have a decrease in feldspar content and increase in grain sorting within wedges present at the upper part of succession bar indication that over time the tectonic impulse declined and thereby the supply become more mature.

The present study therefore documents facies distribution in a distally steeply ramp that intermittently received siliciclastic supply from distant delta.

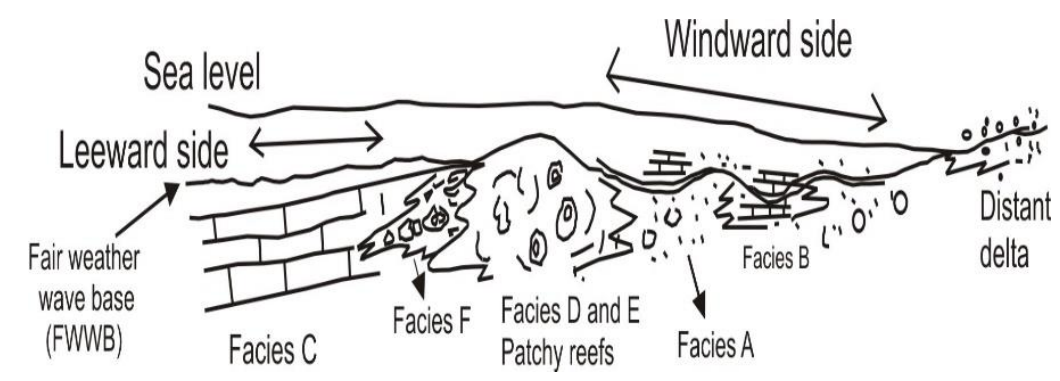

Fig. 5.1. A cartoon illustrating distally steepened ramp geometry for the studied interval of Hajigak Formation. Relative disposition of facies types within overall ramp setting are mentioned along with. 


\section{Reference:}

1. Boggs, S., 2006. Principles of sedimentology and stratigraphy. Pearson Prentice Hall.

2. Driese, S.G. and DottJr, R.H., 1984. Model for Sandstone-Carbonate. AAPG Bulletin, 68(5), pp.574-597.

3. Driese, S.G. and DottJr, R.H., 1984. Model for Sandstone-Carbonate. AAPG Bulletin, 68(5), pp.574-597.

4. Durkoop, A., Mensink, H. and Plodowski, G., 1967. Devonian of central and western Afghanistan and southern Iran.

5. Durkoop, A., Mensink, H. and Plodowski, G., 1967. Devonian of central and western Afghanistan and southern Iran.

6. Folk, R.L., 1959. Practical petrographic classification of limestones. $A A P G$ Bulletin, 43(1), pp.1-38.

7. Griesbach, C.L., 1885. Afghan field notes. Rec. geol. Surv. India, 18, pp.57-64.

8. Griesbach, C.L., 1887. Field notes No. 5-to accompany a geological sketch map of Afghanistan and North-Eastern Khorassan. Indian Geological Survey Publication, 20(2), pp.93-109.

9. Hinze, 1964 Die geologischeEntwicklung der östlichenHindukush-Nordflanke (NordostAfghanistan)BeiheftezumGeologischenJahrbuch, 70 (1964), pp. 19-76

10. James, N.P., 1977. Facies Models 8. Shallowing-Upward Sequences in Carbonates. Geoscience Canada, 4(3).

11. Martina, E., 1963. New data on the Devonian of Afghanistan. R/v./ta/. Pa/eont., LXIX, (4), pp.545-558.

12. Middleton, G.V., 1973. Johannes Walther's law of the correlation of facies. Geological Society of America Bulletin, 84(3), pp.979-988.

13. Mistiaen, B., Brice, D., Hubert, B.L.M. and Pinte, E., 2015. Devonian palaeobiogeographic affinities of Afghanistan and surrounding areas (Iran, Pakistan). Journal of Asian Earth Sciences, 102, pp.102-126. 
14. Plint, A.G., Eyles, N., Eyles, C.H. and Walker, R.G., 1992. Control of sea level change. Facies models: response to sea level change: Geological Association of Canada, pp.15-25.

15. Posamentier, H.W. and Walker, R.G., 2006. Facies models revisited.

16. Read. J.F.1975. Tidal-Flat faies in carbonate cycles, Pillara Formation (Devonian), Canning Basin, Western Australia. In: Ginsburg, R.M (Ed.), Tidal deposition, Springer Verlag Berlin, 251-256.

17. Reading, H.G., 1986. Sedimentary Environments and Facies. USA.

18. Sarkar, S. and Bose, P.K., 1992. Variations in Late Proterozoic stromatolites over a transition from basin plain to nearshoresubtidal zone. Precambrian research, 56(1-2), pp.139-157.

19. Taylor, G. and Walker, P.H., 1986. Tertiary Lake Bunyan, northern Monaro, NSW, part II: Facies analysis and palaeoenvironmental implications. Australian Journal of Earth Sciences, 33(2), pp.231-251.

20. Taylor, G. and Walker, P.H., 1986. Tertiary Lake Bunyan, northern Monaro, NSW, part II: Facies analysis and palaeoenvironmental implications. Australian Journal of Earth Sciences, 33(2), pp.231-251.

Copyright (C) 2021 Mohammad Naeem Sarwary, Mirza Hussain AmirkhaniT, Hassan Malistani, AJRSP. This is an open-access article distributed under the terms of the Creative Commons Attribution License (CC BY NC)

Doi: doi.org/10.52132/Ajrsp.e.2021.31.4 